\title{
Root fracture in patient in the pre-liver transplantation phase
}

\author{
Fratura de raiz em paciente em fase pré-transplante de fígado
}

Fernando Lara D. OLIVEIRA'

Caroline C. SANTA-ROSA'

Bernardo Henrique Silva BAMBIRRA ${ }^{1}$

Elen Marise Castro de OLIVEIRA ${ }^{2}$

Lia Silva de CASTILHO ${ }^{4}$

Maria Elisa de Souza e SILVA ${ }^{4}$

\begin{abstract}
Liver transplantation is the treatment of choice for end-stage liver disease patients, and offers them the possibility of returning to active and longer life. A dental evaluation before transplantation is a recommended prerequisite to avoid oral infections, which can worsen the patient's overall situation. This case report refers to the root fracture of an anterior tooth in a patient who was undergoing dental treatment prior to liver transplantation. On clinical examination, the maxillary right central incisor (11) presented without color change, but with mobility in the buccolingual direction, slight flaring and extrusion, and fistula in the attached gingiva on the distal side of tooth 11. The patient reported that he had suffered a trauma in that region 30 years before. The radiographic examination showed a horizontal fracture of the middle third of the root, associated with bone damage, indicated by a radiolucent area at the distal surface of 11. The proposed treatment consisted of: scraping procedure and straightening of the distal surface, radical endodontic treatment of the coronal portion of the root, subsequent filling with Mineral Trioxide Aggregate and dental immobilization. The clinical and radiographic follow-up at three-monthly intervals allowed us to observe gradual regression of the lesion with bone formation, contributing to maintenance of the patient's general and emotional health, preserving his smile and quality of life.
\end{abstract}

Indexing terms: Liver transplantation. Tooth fractures. Tooth injuries.

\section{RESUMO}

O transplante de fígado é o tratamento de escolha para o estágio final da doença hepática e oferece a possibilidade ao paciente de retorno a uma vida ativa e longa. Uma avaliação dentária antes do transplante é recomendada como pre-requisito para a eliminação de infecções orais, as quais podem piorar o quadro do paciente. Este relato de caso se refere a uma fratura radicular de dente anterior em um paciente em tratamento odontológico prévio ao transplante de fígado. No exame clínico, o incisivo central superior direito (11) apresentava-se sem alteração na coloração mas com mobilidade no sentido vestíbulo-lingual, ligeira vestibularização e extrusão, e fístula na gengiva inserida na distal do 11. O paciente relatou ter sofrido traumatismo na região há mais de 30 anos. Ao exame radiográfico, foi identificada uma linha de fratura radicular horizontal no terço médio, associada à lesão óssea indicada por uma área radiolúcida na superfície distal do 11. O tratamento proposto para o caso envolveu procedimentos de raspagem e alisamento subgengival da superfície distal, o tratamento endodôntico radical da porção coronária radicular com posterior obturação com Agregado Trióxido Mineral e imobilização dental. O acompanhamento clínico e radiográfico, em intervalos de três meses, permitiu observar a regressão gradual da lesão, com formação de osso no local, contribuindo para manutenção do quadro de saúde geral e emocional do paciente, preservando seu sorriso e sua qualidade de vida.

Termos de indexação: Transplante de fígado. Fraturas dos dentes. Traumatismos dentários.

\section{INTRODUCTION}

Liver transplantation is the treatment of choice for end-stage liver disease patients and offers them the possibility of returning to an active and longer life'.

Until the decision to undergo this alternative treatment, the patient's health status worsens, either due to the disease symptoms themselves or to consequences of the procedures in preparation for transplantation. This has been observed by researchers, who carried out studies that evaluated some aspects of patients, such as depression and anxiety, before and after transplantation2.

A dental evaluation is a recommended prerequisite, especially because the presence of drug-induced immunodeficiency status in these patients leads to the risk of opportunistic infections. The dental foci of infection must be eliminated before transplantation procedures in order to avoid their dissemination, which can lead to

\footnotetext{
1 Universidade Federal de Minas Gerais, Faculdade de Odontologia. Av. Presidente Antônio Carlos, 6627, 31270-901, Belo Horizonte, MG, Brasil. Correspondência para / Correspondence to: FLD OLIVEIRA. E-mail: <fernando_ldo@hotmail.com>.

2 Universidade Federal de Minas Gerais, Faculdade de Odontologia, Departamento de Odontologia Restauradora. Belo Horizonte, MG, Brasil.
} 
serious consequences. The dental examination involves the anamnesis, clinical and radiographic evaluation, enabling the appropriate care planning. Whenever possible, it is important for teeth to be maintained or restored to ensure proper development of oral functions and successful social integration of patients, who are already overloaded with stress by waiting to recover their health by means of transplantation ${ }^{3}$.

Among several mouth injuries, dental root fractures occurring in dentin, cementum and pulp account for 0.5 to $7 \%$ of all dental lesions, and are most common in young aged people from 10 to 20 years old. Fractures are classified according to: the direction - horizontal or vertical - in which they occur; number of fracture lines, single or multiple; or by their location in the root, cervical, middle and apical thirds. Diagnosis is based on clinical and radiographic examinations and characteristics similar to extrusion, dislocation and fracture of the alveolar process may be found ${ }^{4}$.

Horizontal fractures are mainly observed in the anterior region of the maxilla5; occur most often in the middle third of the $\operatorname{root}^{6}$; and almost $75 \%$ of these affect the maxillary central incisors ${ }^{7}$; in male patients, as a result of trauma associated with motor vehicle accidents, sports, assaults and other factors ${ }^{8}$. The fractured tooth prognosis is influenced by factors such as the degree of dislocation, stage of root formation, fracture location, interval between trauma and treatment, and type of dental trauma ${ }^{9}$.

Depending on variables, such as age of the patient, the pulp and periodontal health status, mobility of the coronal fragment, fracture location and stage of root formation, it is possible for the repair of horizontal fracture to occur ${ }^{10}$.

The repair process of root fractures can be divided into three categories: (i) repair with calcified tissue; (ii) repair with interproximal connective tissue; (iii) interproximal inflammatory tissue without repair ${ }^{11}$. The way the repair occurs depends on the pulp, dentin, cementum and alveolar bone health status and degree of displacement of the fragments ${ }^{10}$. If the pulp is ruptured, the coronal region must be revascularized before the fracture will repair. There is no precise method to evaluate this process, however, pulp or apical periodontal ligament cell invasion is believed to occur ${ }^{5}$. If the pulp becomes necrotic, inflamed and infected, radical endodontic treatment of the coronal portion is necessary ${ }^{12}$, otherwise the infection may spread to the underlying tissues, consequently leading to tissue destruction, tooth mobility, pain and even tooth loss ${ }^{13}$.
This case report refers to a horizontal root fracture of the maxillary central incisor, tooth 11, in a 46-year-old patient, undergoing dental treatment prior to liver transplantation. The authors report the procedures adopted for maintenance of the tooth, and to avoid the negative impact on the patient's quality of life.

\section{CASE REPORT}

The patient, a 46-year-old man patient received dental treatment in the "Extension Project on Dental Care for Bone Marrow and Liver Transplanted Patients", School of Dentistry, Federal University of Minas Gerais (FOUFMG), in partnership with the Clinical Hospital of the same University, to prepare him for liver transplantation. The protocol procedures were completed: signing the term of free and informed consent for dental treatment and permission to use the information for the purposes of teaching and dissemination, preserving his right not to be identified, dental records, radiographic examinations, scaling and polishing and data survey to prepare the planning of care. The primary disease that led to the patient being placed on the waiting list for liver transplantation was ethanol cirrhosis. When we started the root canal treatment, the patient was taking the following medicines: propranolol (40 mg), furosemide (40 mg), spironolactone (100mg), Lactulose. From the priority point of view of the medical procedure, the patient was not expected to be summoned for transplantation, considering his biological indicators that showed he was stable. At the time of dental treatment, his hematological parameters showed that the number of white and red blood cells were within the normal range; number of platelets and MPV, slightly lower than normal $(116 \times 103 / \mathrm{mL}$ and $6.6 \mathrm{fL})$; INR within the normal value ( $1: 48)$. He had no edema, pain or recent reports of medical hospitalization.

On clinical examination, tooth 11 showed no color change, but there was grade 2 mobility (buccolingually), slight flaring and extrusion. The probing depth was $4 \mathrm{~mm}$ on the distal side and $2 \mathrm{~mm}$ on the other sites. There was also a fistula next to the inserted gingival papilla between the teeth 11 and 12 .

After panoramic and periapical radiographic examination, a horizontal root fracture was detected in the middle third of the root of the maxillary right central incisor, associated with a bone lesion, indicated by a radiolucent area at the distal surface of the tooth root (Figures 1 and 2). 


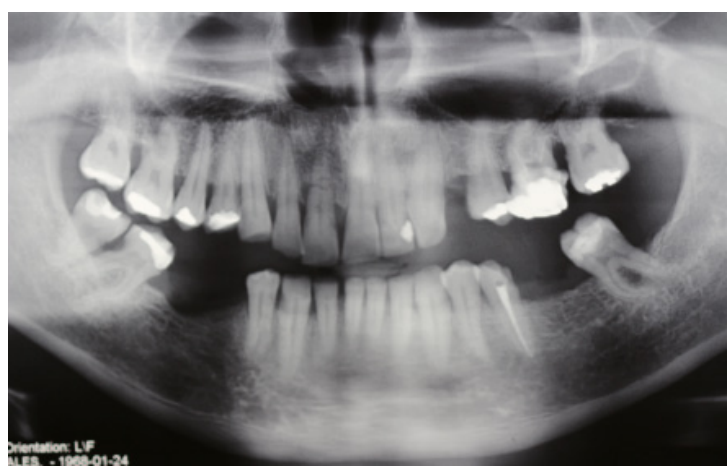

Figure 1. Initial panoramic radiograph.

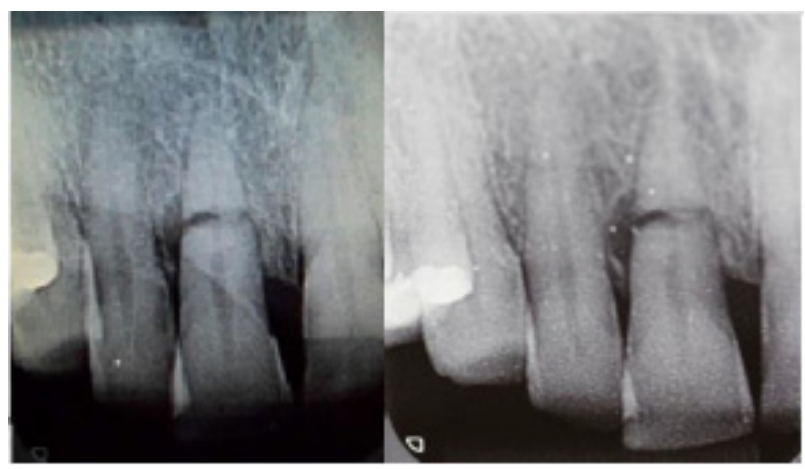

Figure 2. Initial periapical radiographs.

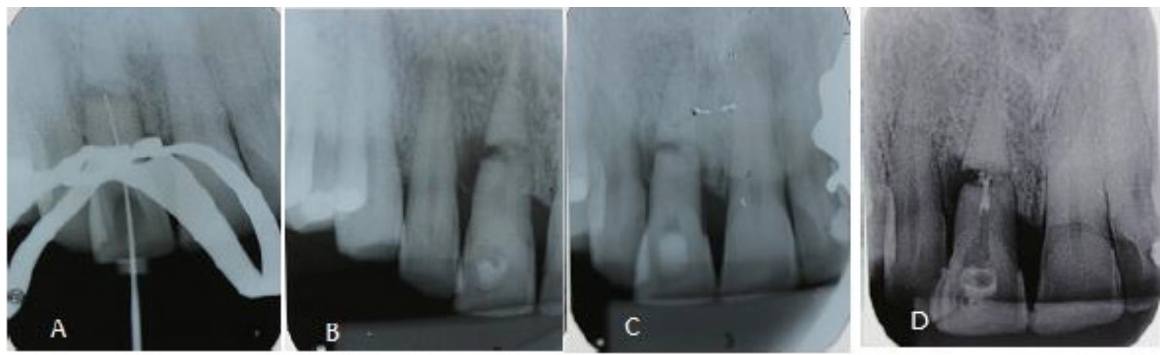

Figure 3. A) Instrumentation; B) First use of calcium hydroxide; C) Two months after second exchange of calcium hydroxide and D) Filling with MTA.

The patient reported having suffered a trauma in adolescence, when playing with a friend nearly 30 years ago; he had received no treatment at the time. He complained about the increased tooth mobility and emphasized that he did not want to have the tooth extracted.

Tooth 11 responded positively to electric pulp sensitivity testing (Pulp Tester Digital ${ }^{\circledR}$, Odous de Deus, Belo Horizonte, MG, Brazil) and to cold pulp sensitivity testing (Endo-Frost, Roeko, Langenau, Germany), but of smaller magnitude and more slowly than the homologous tooth. The proposed pulp diagnosis was: asymptomatic irreversible pulpitis that meant radical endodontic treatment of the coronal portion of the tooth root was necessary. Without radiographic evidence of injury to the apical portion, the authors decided to observe this in evaluations during his periodic consultations for preventive maintenance of oral health.

The tissue from the incisal edge of tooth 11 was removed with a conical-trunk diamond bur FG 2068 ( $K G$ Sorensen, Barueri, SP), to relieve contact during the movement of protrusion.

Periodontal probing at the distal surface of tooth 11, with a Goldman-Fox Millennium (Golgran, São Paulo, Brazil) periodontal probe revealed a $4 \mathrm{~mm}$ deep periodontal pocket in the distal region, next to the lesion with adjacent fistula. The dental intervention of choice was subgingival scaling in the region to treat the periodontal pocket and existing fistula. During this procedure the granulation tissue was removed. One week later, we observed that the fistula had regressed.

During the session to perform coronal opening we observed that there was bright red bleeding with fluid consistency of inflamed pulp tissue. The coronal portion was instrumented with K-type hand files (Dentsply Maillefer, Ballaigues, Switzerland) limited to the fracture line. During instrumentation we used $2 \%$ chlorhexidine for canal irrigation, instead of sodium hypochlorite, since this could irritate the periodontal tissues. After cleaning and preparing the canal, we used calcium hydroxide slurry in an aqueous saline vehicle as intracanal medication. At intervals of 2 months, this medication was removed and replaced with the same intracanal medication in tooth 11 . Seven months after opening, the instrumented portion of the root canal was finally filled with mineral trioxide aggregate (MTA) (Angelus, Londrina, Paraná, Brazil).

As final procedures, the tooth was restored with composite resin Filtek ${ }^{\mathrm{TM}}$ Z350 (3M ESPE) shade A2E, and orthodontic archwire fixed to the palatal surfaces of the adjacent teeth (12 and 21) was used to immobilize the tooth. We followed-up the case clinically and radiographically at two-monthly intervals, to control regression of the lesion and compare the results. Over the course of months, it 
was observed gradual regression of lateral lesion with bone formation at the site and clinical reduction in tooth mobility.

\section{DISCUSSION}

For patients awaiting liver transplantation, it is very important to have their dental needs addressed, by eliminating infection, treating active dental injuries or those capable of potential worsening ${ }^{14}$. Treatment should be performed judiciously, although the dental approach may often be radical and mutilating, involving extractions, as an alternative treatment for existing dental problems ${ }^{15}$.

However, tooth loss can have a negative impact on the self-esteem of individuals who are already weakened by the disease itself and treatment ${ }^{15}$, as the smile provides important support for their successful social integration.

Even when there is the need for rapid resolution of dental problems due to patients being released for surgical procedures involving liver transplantation, the first alternative to seek should be to maintain the existing teeth. Especially when patients have good oral health and demonstrate that they are capable of taking care of it, they should be informed about the situation, encouraged and treated to enable them to keep their teeth ${ }^{14}$.

In this case report, the patient E.O.S. was properly enlightened about the diagnosis, stages of treatment, prognosis and need for monitoring, and chose to keep the tooth, when he was faced with the possibility of esthetic loss. Moreover, after scaling, occlusal relief, removing the pulp and dressing with calcium hydroxide, if he were to have been summoned for transplantation, he would have been able to go, without any problem.

The treatment that was offered and provided took into account the patient's hematological tests, especially relative to platelet counts, prothrombin, thrombloplastin and time because of the risk of bleeding, especially in the procedures with risk of bleeding ${ }^{16}$.

As it was unable to specify the origin of the bone lesion observed, the low level of pulp response to sensitivity tests and the need to ensure the patient of a lower possibility of aggravating injuries of dental origin, the approach to the case was multidisciplinary, including endodontic treatment, periodontal treatment, occlusal splinting and subsequent adjustment of the tooth to facilitate its recovery.

Horizontal fracture repair without treatment has previously been reported ${ }^{17}$, but depending on the damage to the pulp, endodontic repair ${ }^{18}$ does not occur without treatment, and may lead to tooth loss in the event of lesion progression and subsequent bone loss.

In this report, there was an abnormal response to pulp vitality tests, in addition to aggression to periodontal tissues. Because of the mobility of the fragment resulting from the physiological and functional movements of the tooth, the periodontal tissue at the distal surface could not be repaired, and a chronic inflammatory process related to the fracture developed. Surrounding the fracture line, a periodontal pocket was formed on the distal surface of the tooth 11 (Figure 2), which was constantly drained through the fistula in the area next to it.

According to the classification of the types of healing, this case fell into the category (iii) interproximal inflammatory tissue without repair ${ }^{11}$.

Endodontic treatment was proposed because there was decreased response when subjected to thermal and electrical testing, and the radiographic examination revealed presence of a radiolucent lesion near the fracture line $^{12}$. The decision to treat only the coronal portion of the fragment was taken because in most cases the apical portion remains vital $^{5}$, and in this case there was no periapical involvement.

Calcium hydroxide was used as intracanal medication to stimulate repair of the fracture. Considered an excellent dressing, it is used for its antibacterial action and for mineralization, inactivation of bacterial enzymes and activation of tissue enzymes ${ }^{19}$. The high $\mathrm{pH}$ of calcium hydroxide is mainly responsible for stimulating the mineralization process and promoting repair, because the active alkaline phosphatase enzyme that stimulates the release of phosphate ions from phosphate esters of the body, react with calcium ions and precipitate in the form of hydroxyapatite ${ }^{20}$.

Concomitantly with endodontic treatment, subgingival scaling was performed in the region distal to the lesion; in addition to curettage, removal of granulation tissue and reduction of inflammation ${ }^{21}$.

During treatment radiographs were taken to monitor the case, and a slight decrease in radiolucency of the lesion was observed during the first change of calcium hydroxide paste. This suggested that occurred deposition of mineralized tissue. Clinically we observed that the canal had remained without inflammatory exudate indicating a reduction in the inflammatory condition.

The use of mineral trioxide aggregate (MTA) as filling material has been shown to be effective for this type of endodontic treatment. The success is justified by 
the satisfactory physicochemical and biological properties of MTA that presents biocompatibility and antimicrobial effects; stimulates the deposition of mineralized tissue; provides sealing conditions; has adequate solubility, and is easy to insert and manipulate ${ }^{22-23}$. It has been shown that the MTA has better properties with respect to root repair and bone formation when compared with other materials traditionally used. It does not affect the antibacterial activity, and more specifically enhances adaptive immune humoral response ${ }^{23}$.

The choice of composite resin to restore the palatal area was justified by its esthetic and mechanical properties. Access to the root canal was opened as conservatively as possible, allowing a small wear of the tooth structure. The purpose of the splint procedure was to completely immobilize the traumatized area, which facilitated periodontal recovery ${ }^{24}$.

\section{CONCLUSION}

Careful clinical and radiographic examination allowed us to identify root fractures that may have been present for years without being noticed by professionals.

Endodontic treatment in cases of horizontal fractures, associated with conservative periodontal procedures may be a way of keeping the teeth of patients in the pre-liver transplantation phase, thereby avoiding the psychological effects of tooth loss and improving their quality of life. Clinical and radiographic findings suggested

\section{REFERENCES}

1. Sirivatanauksorn $Y$, Dumronggittigule $W$, Limsrichamrern $S$ Iramaneerat C, Kolladarungkri T, Kositamongkol P, et al. Quality of life among liver transplantation patients. Transplant Proc. 2012;44(2):532-8. doi: 10.1016/j.transproceed.2011.12.056.

2. Stewart KE, Hart RP, Gibson DP, Fischer RA. Illness apprehension, depression, anxiety, and quality of life in liver transplant candidates: implications for psychosocial interventions. Psychosomatics. 2014;55(6):650-8. doi: 10.1016/j.psym.2013.10.002

3. Baumann AJ, Wheeler DS, James $M$, Siegel A, Navarro VJ Benefit of early palliative care intervention in end-stage liver disease patients awaiting liver transplantation. J Pain Symptom Manage. 2015; 50(6):882-6.e2. doi: 10.1016/j. jpainsymman.2015.07.014

4. Andreasen JO, Andreasen FM. Textbook and color atlas of traumatic injuries to the teeth. Copenhagen, Denmark: Munksgaard; 1994.

5. Andreasen FM, Andreasen JO, Andersson MC. Textbook and color atlas of traumatic injuries to the teeth. 4th edn. Oxford: Blackwell; 2007. that even after 30 years, there was repair of the fracture, possibly due to changes in the patient's systemic, occlusal, periodontal and pulp conditions.

The MTA was a good option for root canal filling in a case in which greater action of mineralized tissue deposition was required.

Treatment should always be sensitively proposed, taking into consideration the patient's emotional and health condition, the need for, and options of treatment; especially the maintenance of teeth and as a result, maintenance of the patient's quality of life.

The interaction between a multidisciplinary team allowed discussion among professionals in several specialties such as dental prosthesis, endodontics and periodontics that met the treatment needs.

The periodic clinical and radiographic evaluation of this case was essential for observing the effectiveness of treatment.

\section{Collaborators}

FLD OLIVEIRA, CC SANTA-ROSA, BHS BAMBIRRA, EMC OLIVEIRA and MES SILVA assisted the patient in the case here reported and in writing the paper. LS CASTILHO contributed in the final writing, mainly in discussion. All authors made substantial contributions to all stages of this paper and approved the final version and its submission to this journal.

6. Chala S, Sakout M, Abdallaoul F. Repair of untreated horizontal root fractures: two case reports. Dent Traumatol. 2001;17(5):240-3. doi: 10.1111/j.1600-9657.2009.00774.x

7. Majorana A, Pasini S, Bardellini E, Keller E. Clinical and epidemiological study of traumatic root fractures. Dent Traumatol. 2002:18(2):77-80.

8. Kamburoglu K, Ilker CA, Grondahl HG. Effectiveness of limited cone-beam computed tomography in the detection of horizontal root fracture. Dent Traumatol. 2009;25 (3):256-61. doi: 10.1111/j.1600-9657.2009.00770.x

9. Andreasen JO, Andreasen FM, Mejare I, Cvek M. Healing of 400 intra-alveolar root fractures. 1. Effect of pre-injury and injury factors such as sex, age, stage of root development, fracture type, location of fracture and severity of dislocation. Dent Traumatol. 2004;20(4):192-202. doi: 10.1111/j.16009657.2004.00279.x

10. Kusgoz A, Yildirim T, Tanriver M, Yesilyurit C. Treatment of horizontal root fractures using MTA as apical plug: report of 3 cases. Oral Surg Oral Med Oral Pathol Oral Radiol Endod. 2009;107(5):e68-72. doi: 10.1016/j.tripleo.2009.01.031

11. de Jesus Soares A, Nagata JY, Rocha Lima TF, Zaia AA, de Souza- 
Filho F J. Horizontal root fracture repair in teeth with different root development stages: report of two cases. Int J Dental Clin. 2013;5(3):25-8

12. Flores MT, Andersson L, Andreasen JO, Bakland LK, Malmgren $B$, Barnett $F$, et al. Guidelines for the management of traumatic dental injuries. I. Fractures and luxations of permanent teeth. Dent Traumatol. 2007;23(2):66-71.

13. Márton IJ, Kiss C. Overlapping protective and destructive regulatory pathways in apical periodontitis. J Endod. 2014;40(2):155-63. doi: 10.1016/j.joen.2013.10.036

14. Little JW, Falace DA, Miller CS, Rhodus NL. Dental management of the medically compromised patient. 8th ed. St. Louis, MO: Mosby Inc.; 2012.

15. Costa JLBM, Silva NCS, Pinto Junior AAC, Abreu MHNG, Gomez RS, Silva MES. Tratamento odontológico prévio a transplante de células tronco-hematopoiéticas: um relato de caso clínico. Arq Odontol. 2014;50(1):20-7.

16. Radmand R, Schilsky M, Jakab S, Khalaf M, Falace DA. Preliver transplant protocols in dentistry. Oral Surg Oral Med Oral Pathol Oral Radiol. 2013 Apr;115(4):426-30. doi: 10.1016/j. oooo.2012.12.006

17. Verdugo-Avello FJ, González E, Pedemonte C, Vargas I. Fracturas radiculares en pacientes adultos: propuesta de tratamiento actual. Rev Esp Cir Oral Maxilofac. 2014;36(2):54-8. doi: 10.1016/j.maxilo.2012.11.008

18. Verma PK, Srivastava R. Calcium hydroxide: a boon in complete healing of horizontal apical one-third root fracture. Dental Hypothes. 2012;3(3):121-5. doi: 10.4103/2155-8213.103936
19. Dixit S, Dixit A, Kumar P. Nonsurgical treatment of two periapical lesions with calcium hydroxide using two different vehicles. Case Reports Dent. 2014;2014:1-4. doi: 10.1155/2014/901497

20. Dhull KS, Acharya S, Yadav S. Calcium hydroxide: clinical applications in dentistry. Indian J Dental Sci. 2013;(5):134-6.

21. Barros DL, Franco MMP, Paixão FCO, Freitas SAA, Santana IL, Pereira AFV. Importância da terapia de suporte para a saúde periodontal. Rev Ciênc Saúde. 2014;16(1):5-10

22. Erdem AP, Ozdas DO, Dincol E, Sepet E, Aren G. Case series: root healing with MTA after horizontal fracture. Eur Arch Paediatr Dent. 2009;10(2):110-3.

23. Brito Júnior $M$, Camilo $C C$, Soares JA, Popoff DAV. Biocompatibilidade e capacidade de selamento do agregado de trióxido mineral em perfurações radiculares. RGO, Rev Gaúch Odontol. 2013;61(suppl.):447-52

24. Andreasen JO, Andreasen FM, Meja're I, Cvek M. Healing of 400 intra-alveolar root fractures. 2. Effect of treatment factors such as treatment delay, repositioning, splinting type and period and antibiotics. Dental Traumatol. 2004;20(4):203-11.

Received on: 15/1/2016

Final version resubmitted on: 6/9/2016

Approved on: 20/2/2017 